' Institute of Industrial Economics, the NAS of Ukraine, 2, Zheliabova St., Kyiv, 03057, Ukraine, +380 44200 557, vishnevsky@nas.gov.ua

${ }^{2}$ Department of Economics, the NAS of Ukraine, 54, Volodymyrska St., Kyiv, 01030, Ukraine, +380442396646, ksi@nas.gov.ua

\title{
TECHNOLOGY GAPS: THE CONCEPT, MODELS, AND WAYS OF OVERCOMING
}

Introduction. The Fourth industrial revolution and accelerated development of Industry 4.0 disruptive technologies are accompanied by the formation of new value creation networks and the redistribution of production facilities that partially return to advanced economies.

Problem Statement. Processes of technological development and new value chains' formation are turbulent, so that some countries have taken lead in the sphere of technology, while others have become outsiders. Between them, new technology gaps are emerging or existing ones are changing, and this, in turn, has a critical impact on the development of national economies: productivity, job creation, profitability of businesses, employment, and population income.

Purpose. To develop a framework for defining the concept and estimating the size of technology gaps between countries with different levels of industrial development in the context of the Fourth industrial revolution.

Materials and Methods. Historical analysis of technology gap economic concepts, statistical analysis of indicators of economic and $R \mathcal{E} \mathcal{D} D$ development of world economies, economic and mathematical modeling of the cyber-physical technology life cycle.

Results. Within the economic theory of the technology life cycle, an emendated concept of technology gap has been proposed. It is mainly related to jump transition from one technology curve to another. To assess the size of technology gaps, a logistic function has been proposed. It determines the relationship between labor productivity and capital/labor ratio taking into account the interdependence of physical and digital capital. Using this function, technology gaps between industrialized European economies and Ukraine, which manifest themselves as multiple lags in productivity, have been identified.

Conclusions. In order to reduce the technology gaps between Ukraine and European countries, it is necessary to create a new, innovation-oriented business ecosystem that is formed in the course of gene-cultural-technological co-evolution and, above all, requires a set of measures to accelerate the development of Ukrainian REFD sphere, as well as related culture and institutions.

Keywords: industrial revolution, technology gap, cyber-physical technology, technology curve, and business ecosystem.

Citation: Vishnevsky, V.P., Harkushenko, O.M., and Kniaziev, S.I. Technology Gaps: the Concept, Models, and Ways of Overcoming. Sci. innov. 2020. V. 16, no. 2. P. 3-17. https://doi.org/10.15407/scine16.02.003 
The fourth industrial revolution accelerates the technological development and changes all spheres of human activity. The world is getting more digitalized, the human being is becoming more cybernetic-oriented, the production is controlled by artificial intelligence and robots. In the upcoming years, the Internet of Things can radically change manufacture, power engineering, agriculture, transportation and other sectors of the real economy accounting for almost two-thirds of world GDP [1]. In fact, it is a global process of forming new networks of value creation and redistribution of production facilities that are returning, at least, partly, to advanced economies [2] and new global centers of economic power.

Therefore, nowadays, the problems of technological development in the context of the fourth industrial revolution and the formation of Industry 4.0 has attracted considerable attention. There have appeared numerous publications on the processes of Industry 4.0 formation [3-5], the use of new key technologies, such as microand nano-electronics, nanotechnology, industrial biotechnology, advanced materials, photonics, big data, and blockchain, the effects of digitalization and robotic automation of production using artificial intelligence capabilities [7, 8], etc. [6, 7].

These processes of technological development are very irregular, turbulent. There are leaders, and there are outsiders. Between them, there are emerging new technology gaps or, conversely, decreasing and disappearing the existing ones, which have a critical impact on national economies: output, job creation, business profitability, employment, and household income. Against this background, it is extremely important to determine the place of every country in this newly created reality.

Today, there are many different ratings: by innovation [10], economic complexity [11], digitization [12], etc. All of them, on the one hand, are really helpful and allow countries to critically evaluate themselves and to make the necessary management decisions to enhance their strengths and to eliminate weaknesses. On the other hand, such rankings are nothing more than rankings, usually based on expert evaluations, which does not make it possible to determine, in terms of usual economic criteria, the size of gaps between certain countries and groups of countries, how they can be estimated, and which steps are necessary to overcome, or at least to reduce, critical technological backwardness of national industries from the most industrialized economies, based on these estimates.

Proceeding from the above, the purpose of research is to develop a conceptual approach to defining the concept and estimating the size of technology gaps between countries with different levels of industrial development in the conditions of the fourth industrial revolution and accelerated development of Industry 4.0 technologies.

\section{PROBLEMS RELATED TO CONCEPTUALIZATION AND DEFINITION OF TECHNOLOGY GAPS}

The process of technological development worldwide is not uniform and influenced by many factors that differ depending on the place and time, so that some countries today are technological leaders, while others are outsiders. The distance between the level of their development in the post-Soviet scholarly research literature was called "the technology gap". In English-language academic literature, the situation is not so unambiguous: there are two terms "technology gaps" and "technology lags" and both them are used by researchers.

According to B. Godin, a researcher in the field of innovation history, the concept of "lags" ${ }^{1}$ and "gaps" comes from the theory of cultural lags in sociology. In 1920-1930, its founder, the American sociologist W.F. Ogburn, suggested that in society there was a significant increase in the number of inventions, most of which were not implemented in practice because of a significant

${ }^{1}$ B. Godin defines lag as time interval between the appearance of invention and its commercialization $[13,35]$. 
lag of the tangible culture from the intangible (adaptive) one. That is, such a society may not be ready for new technical means and technologies, and for overcoming the lag needs consolidated efforts of the whole society [13, 35-36].

Almost 30 years after the creation of the cultural lag theory, it evolved into an economic theory.

At the first stages, the idea of how different levels of technological development could affect the economy was developed in the context of international trade theory, in particular, the famous Heckscher-Ohlin model [14], which explains export/import specialization of countries by surplus/deficit of individual production factors.

M. Posner, a British economist, is believed to be an author of one of the first ideas of technology gaps. In his research International Trade and Technical Change (1961), he notes that if two countries have the same factors of production, the same structure of industry, and a parity in terms of balance of trade, then the only thing that can turn the tide in favor of one of them (all other things being equal ${ }^{2}$ ) are innovations and implementation of technical and technological changes $^{3}$ [15, 323].

If one country takes the lead, to overcome the gap the other one needs time for learning (adaptation of innovation by enterprises, consumers, competitors); for imitation of innovation in the domestic market (change in the technical and technological conditions of business operation in order to obtain the same profits as innovating enterprises); for dissemination of technology until it becomes typical for the industry); for imitation of innovation in the foreign market (development of new technologies by foreign competitors of the innovating firm); and for generation of demand.

\footnotetext{
${ }^{2} \mathrm{M}$. Posner does not take into consideration transportation costs, difficulties related to the trans-border traffic, government monetary and fiscal policies.

${ }^{3}$ Provided they take place in the same industry. If technological transformations occur in the one industry, in one country, and in other industry, in the other country, the balance can be kept, but the international trade structure changes.
}

Each such period of time is called 'lag", "learning lag”, "domestic imitation lag" "foreign imitation lag", and "demand lag". The longer the duration of each one, the greater the opportunity for innovative enterprises to make higher profits, and the harder it for competitors, both within and outside the country, to overcome the gap.

According to M. Posner, in aggregate, all lag periods are called "net lag". The author defines it as:

$$
\text { Net lag }=L-\lambda,
$$

where $\lambda-$ is demand lag; $L$ is total imitation lag, $L=l_{1}+l_{2}+l_{3} ; l_{1}-$ is foreign imitation lag; $l_{2}$ is domestic imitation lag; $l_{3}$ is learning lag.

This time interval may be different for different innovations (product, process, organization, etc.), different industries and different countries, but this has not been thoroughly discussed by the author.

Theoretically, at the end of net lag, a country that is chasing the innovating country can either master the production of a similar product or reduce its costs on an already existing product and abandon the import of innovative product, which should eventually lead to a rebalancing of trade between countries.

However, another problem arises: during this time, the innovating country can accumulate new knowledge and resources (including those from international trade) and invest them in new developments and solutions. And if such innovations are continuous, one after another, or arise simultaneously over a period that is shorter than the duration of the net lag, the outsider country, in fact, have no chance of catching up with the lea$\operatorname{der}^{4}$. That is, not only the time for imitation and adaptation of new technologies (the net lag), but also the rate of innovation (number, speed, and productivity) is important to determine the impact of technological progress on international trade.

M. Posner defines the net lag and the rate of innovation together as dynamism of national eco-

\footnotetext{
${ }^{4}$ Except for the case where the outsider country is realizing innovations in an industry other than that where it is not a leader.
} 
nomy. It is the ability of economy to quickly and massively imitate the best technologies and products and/or to create new ones. It shows how fast the economy and positive trade balance will grow. In addition, such a country will possess sufficient resources and time to ensure maturing the next innovations and retaining its leadership.

In the 1970s, attempts were made to determine the impact of technology and technological changes on international trade in a formalized manner, in particular, a model proposed by influential American international trade economist R. Jones [16], which is an evolution of the model by Heckscher-Ohlin and their followers. That is, it is a theoretical model of international trade balance, in which there are two countries, each producing two types of goods (manufactures (industrial commodities) and food) using two types of resources (labor and land). The factors of production in each country are considered to be fully operational and immobile.

The author notes that technological innovation helps reduce the price of products due to a relative decrease in the cost and the amount of resources required for this purpose. Therefore, the innovating country gains competitive advantages over its trade partner and can export larger quantities of its products at a lesser cost.

R. Jones set a task to determine how the difference in the production functions of countries emerging from the influence of technical innovation changed the basic model of trade balance. At the same time, like his predecessors, he assumed that the consumer preferences were the same in both countries and ignored monetary and fiscal policies of the countries as well as transportation costs.

To solve this problem, the researcher analyzed relative change in prices for goods within the model:

$$
\begin{gathered}
\left(\widehat{P}_{M}-\widehat{P}_{F}\right)=|\Theta|(\widehat{w}-\widehat{r})-\left(\pi_{M}-\pi_{F}\right), \\
|\Theta|=\Theta_{L M}-\Theta_{L F},
\end{gathered}
$$

where $M$ is manufactures (industrial commodities); $F$ is food; $L$ is labor; $\widehat{P}_{M}, \widehat{P}_{F}$ are changes in prices for manufactures and food, respectively; $\widehat{w}$ is relative change in wage; $\hat{r}$ is relative change in land rent; $\pi_{M}, \pi_{F}$ is relative decrease in the cost of manufactures and food, respectively; $\Theta_{L M}, \Theta_{L F}$ is labor share in the manufactures and food, respectively.

A sign of $|\Theta|$ shows which goods are more laborintensive. If in both countries the manufactures are more labor-intensive (i.e., $|\Theta|$ is positive), the country with lower wage has an advantage.

Equation (2) makes it possible to clarify this statement in the light of the impact of technological change: the production of more labor-intensive goods may be more expensive in the low-wage country if the other country has a sufficiently large technological advantage in producing such goods. That is, if technological innovation is considered, then, according to the theory of comparative advantage, in this case, the difference in labor productivity is crucial.

At the same time, if land (an immobile factor of production) is replaced by capital and the latter is assumed a mobile factor (for example, foreign investment), in this case, technical innovation may lead to an increase in capital investment. This eventually leads to country's specialization in the production of goods that provide a higher return on investment.

Further, through international trade, prices for factors of production in international markets may have become on a par with each other, but the shares of these factors in the cost of final products (innovative in the one country and non-innovative in the other) are increasingly different, and the technological development of these countries is different as well. Thus, products manufactured in different countries may be the same, however, because of differences in the prices and the correlation of factors of production, the national production functions differ.

In general, a new technology may be transferred to a less developed country, but it requires significant capital investment (for example, foreign investment), skilled workers, and managers familiar with it. At the same time, as M. Posner 
emphasizes, such transfer requires, at least, time and other inputs for mastering the skills to use them. If it is impossible to borrow a new technology for some reason, in order to catch up with its competitors such a country needs to develop its own technology, which also takes time and money. That is, according to M. Posner, the transfer of technology and/or the creation of its own one is associated with the lag and its closing.

As a whole, like the previous studies based on the Heckscher-Ohlin model, R. Jones's model is very abstract. Moreover, statements on differences in the production functions of countries with different level of technological development and the transfer of new technology from one country to another are not formalized. They are nothing more than subjective conclusions of the author.

A notable further step in understanding the technology gaps was the well-known monograph by McKinsey $\mathcal{E}$ Company former director R. Foster Innovation: The Attacker's Advantage (1986) $[16 ; 18]$, in which he considers the problem from the standpoint of the dynamics of the technology itself and its life cycle described by S-curve rather than in the context of international trade theory and comparative advantages.

R. Foster's idea was that while developing, every new technology passes through three main stages. At first, each technology requires a considerable amount of time, money and effort to bring it to a useful product. At the next stage, at the upper section of S-curve, a considerable return on the use of this technology is achieved at a relatively low cost. At the final stage of the technology life cycle, significant investments result in a incomparably smaller return. That is, at the final stage, the technology has exhausted its capacity and needs to be replaced by a new one.

At the same time, R. Foster notes that S-curves almost always go in pairs (Fig. 1), and the technology gap [18, 273]) conveys the sense of a break from one technology to another.

That is, unlike the previous ideas, for example, of M. Posner, according to R. Foster, the technology gap is the replacement of one technology by

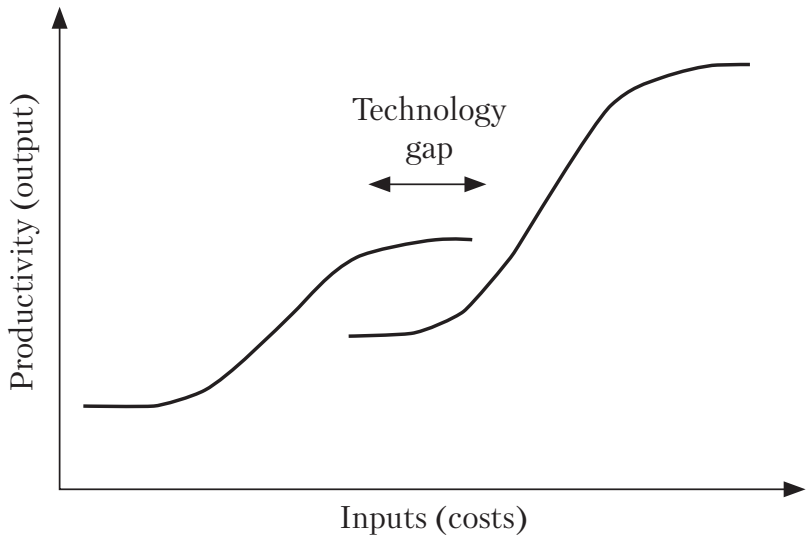

Fig. 1. Technology life cycle and technology gaps in the context of cyber-physical systems of Industry 4.0

another (often, radically different from the previous one), a steep transition (turbulent, disruptive development), rather than a period of time during which it is necessary to learn a new technology, to imitate it or to create a similar one (laminar, gradual development).

R. Foster did not propose any specific methods for constructing technology curves and determining gaps. There were no formal models of these curves in his works. As an example, according to the available statistical information for a certain period of time, he analyzed the technology curve in the field of creation and implantation of an artificial heart, with time spent for research as inputs and lifetime of patient with an implant as outcome. The limitation of application of each technology, the assessment of technology gaps, as well as the definition of measures to overcome them is an independent task of each corporation that wants to remain a leader $[18,87]$.

The conceptual vision of R. Foster's problem [16] involves the consideration of technology curves and discontinuities at the micro level, i.e. at the level of individual enterprises and corporations (groups of companies). This complicates the analysis in terms of assessing the technological development of national economy as a whole, since the technology curves in different sectors of industry can overlap, with different stages of these different technology curves inevitably intersecting, which complicates generalization of 
situation in the economy as a whole and crossnational comparisons.

Another approach to understanding the problem of technology gaps enabling cross-national comparisons was proposed by Norwegian researcher J. Fagerberg. In his research published in 1988 [19], he put forward the theory of technology gaps in economic growth, which was based on the concept of evolutionary economics [20]. In his opinion, this theory was a kind of response to the inability of neoclassical theories of economic growth to explain the particular role of innovation and diffusion of production technologies in the context of global economic growth. According to him, technology gaps are significant technological differences between rich and poor countries [21, 1292].

J. Fagerberg developed a model linking economic growth and balance of payments within the framework of international competitiveness theory. In this model, his approach to assessing the level of technological development of countries is of particular interest. According to him, changes in exports and imports depend on a ratio of the technological development of the country under review and that of advanced economies. He designated it as $\frac{Q}{Q^{*}}$, where $Q$ is technological development of the country under review and $Q^{*}$ is technological development of advanced economies [19].

It follows that in the case of comparing the technological development of advanced economies, this ratio approaches 1 , and as the difference in technological development of countries increases, its value tends to zero. A rather high ratio means that there is a technology lag between countries, while very low one is an evidence of a technology gap.

An important next step in the combination of macro and microeconomic approaches to understanding the processes of technological development and technology gaps is Technological Revolutions and Financial Capital. Dynamics of Bubbles and Golden Ages (2002) by British and Venezue- lan economist C. Perez [22, 23]. She has proposed an effective concept of technological development, which is a combination and further evolution of N. Kondratieff's long waves of development [24], J. Schumpeter's idea of the role of innovators and creative destruction [25], and R. Foster's concept of technology gaps [16], as well as contains elements of the world-system theory [26].

According to C. Perez, about every 50 years there are radical technology innovations or big revolutionary leaps in technology [23, 60], which fundamentally change not only the industry where they originated, but also all other industries, spheres of economy, society, nation state, and government institutions. Such revolutionary innovations, as well as other related technologies and innovations, transform production, become a driving force of industrial revolutions and cause the so-called long Big Waves. According to Perez, they look more like Foster's logistical technology curves, rather than typical Kondratieff's long waves. They are also interrupted and superimposed upon changing technology paradigms (i.e., when one technology becomes obsolete and is replaced by a new one).

In her research, C. Perez has advanced from R. Foster's theory of discontinuities to the macro level and chosen revolutionary innovations affecting not only one industry, but the entire economy and even society, forcing the latter to make significant changes in terms of technology management, as well as to revise the established rules for its operation. In this case, the technology curves, if considered from a macro level viewpoint, and long technology waves are smoothed, and thus the possibility to estimate and to simulate them becomes more real.

C. Perez almost has not used the term "gap 5", but notes that the development of individual in-

${ }^{5}$ C. Perez defines "gap" as inequality in terms of income difference between the richest strata and the rest of population, increase in the share of poorest people, and in terms of difference between GDP values in constant and current prices in the phase of aggressive technology development and in the disruptive moment [23, 99-111]. 
dustries over a long wave is divergent. Such a divergence in the development is observed between new activities and old ones that have become traditional within a new paradigm of technological development [23, 61]. As time goes by and new technologies are diffusing among more and more economic entities, this divergence may diminish, in particular, because of disappearing outdated economic activities.

In addition, when it comes to diffusion of new technologies in the world during the next Big Wave, one can observe a lagging. Disruptive technologies mature, "explode", and develop in a core country, and later investors move from that country throughout the world searching for comparative advantages and opportunities to expand already saturated markets [23, 63, 95].

According to Perez's conceptual approach, the difference in technological development between countries is a result of combination of various factors: level of general economic development, available infrastructure, experience, institutional conditions, existing R\&D base, investments in $\mathrm{R} \& \mathrm{D}$, and time for implementation of new technologies. So, the concept of difference in technological development of countries and the reasons for this phenomenon, as mentioned by the researcher, can also be considered as a further evolution of M. Posner's ideas of technology gaps.

The fruitful idea of the cyclical nature of innovation proposed by C. Perez has generated many other studies in this field, among which it is advisable to draw attention to research by $\mathrm{M}$. Hirooka [27] who, based on the analysis of a large body of data, has hypothesized the existence of a link between innovations and Kondratieff's large cycles and proved that the diffusion of innovation is synchronized with an increasing cycle wave; A. Akayev [28] who has developed a mathematical model of long-term macroeconomic growth, which takes into account the effects of cyclical fluctuations; V. Dementiev [29] who focuses on the interaction of extractive and inclusive institutions in the context of technology change, and others.
In 2008, the World Bank proposed a comprehensive index to assess the technological development of countries and, accordingly, to make comparisons between countries [30, 4-5].

Technological achievements are evaluated using this index by identifying how widely different technologies are being used and/or generated in each country. Such intensity is estimated by the four parameters:

1) the scale of scientific innovation and invention;

2) penetration of older innovations;

3 ) penetration of recent innovations;

4) absorption of foreign innovations in domestic production.

The World Bank experts consider technology gap as differences in these four indicators when comparing the high- and the low-income countries. They have noted that because of low income, scarce technical skills, and lack of appropriate infrastructure the latter absorb and use only $1 / 4$ of the former's technologies [30, 7].

It should be noted that the concepts of "technology gap" and "technology lag" had long been used as synonyms. However, recently, experts from leading international institutions and organizations have begun to use these terms more carefully.

Thus, when comparing the technological development of countries, experts of the International Monetary Fund [31] use the concept of "technology lag". The "technology gap" is used for contraposing the new/upgraded and the nonmodernized businesses. It can be overcome by replacing outdated technologies and organizational routines with new ones.

Often, the term "technology gap" is used in the context of labor, skills, and qualifications required for the use of new technology.

Thus, the International Monetary Fund report [32] states that as of 2018, there are significant gaps in the methodology and methods of collecting statistical information on labor (productivity, new economic activities, etc.).

Delloitte, one of the four world largest consulting and auditing firms, uses "gap" only in terms 
of skills required to work with new technology and the lack of staff that possesses them [33].

Similarly, the term "gap" is used by L. Caldwell, $E Y$ expert in the field of audit and consulting. She notes that, because of skills gap, the number of unfilled manufacturing jobs in the US may reach 2.4 million by 2028 . That's an increase of nearly 2 million in just 10 years (from 2018). And the workers to fill the vacancies is yet to come [34].

To summarize the above mentioned, it should be noted that although the concepts of "technology gap" and "technology lag" were proposed almost 60 years ago, so far, neither their clear definition nor difference between them have been given in the academic literature and reports of leading international organizations (IMF, World Bank, etc.). Moreover, in English-language literature, these terms are often used synonymously. Sometimes, for the reason of political correctness, the term "technological lagging" is used with respect to developing countries as a softened version of the term "technology gap".

Nevertheless, the analysis made in the paper has showed that it is appropriate to distinguish these concepts within the concept of technology life cycle. Therefore, in order to make it clear, it is suggested to use the following definitions

Technology lag is a small difference in technological development, mainly, between countries with similar income, which are developing within similar technological paradigm. The technology lag is characterized by evolutionary innovations that enable one country to gain short-term competitive advantages and can be fairly quickly replicated by the other country (through imitation or development of its own innovation) at a relatively low cost and time, so that the other country can regain the lost competitive positions. In this case, we are talking about the same S-curve.

Technology gap is a significant distance between countries in terms of technological development, the emergence of which is possible in the two ways:

1) between countries with similar income and the same technological structure in the case of a large-scale disruptive innovation belonging to a higher technological structure, in one of them, or in the case of a set of evolutionary innovations emerging so fast and massively that do not allow the other country to imitate them or to create its own innovations in a short term, to regain the lost competitive positions in world markets;

2) between economies with different technological structure, and mainly with a large gap in income.

In this case, it is either a transition from one S-curve to another, or different S-curves.

Such a definition of technological gap is stricter than that suggested by M. Posner, because in the case of countries possessing different technological structures, the outsiders actually remain in the position of forever underdogs who can only try to approach the innovator countries, but not to have caught up with them, since the dynamism of their technological development (the scale and rate of innovation), all other things being equal, is always lower than that of the leaders. Only a favorable coincidence in combination with consistent and persistent efforts of society to build a national innovation system and to create a relevant culture can radically change the situation (as, for example, it has taken place in South Korea and in China).

In this context, it is important to emphasize that in this case, it is a long-term technology lag, as measured in the physical productivity of the technology, rather than economic backwardness in terms of, for example, GDP per capita. GDP can be raised relatively quickly by massively introducing well-developed technologies from the top of S-curves, but this does not help boost the country's competitive position in a long run. So, unlike the widespread point of view, massive innovation is not a key to strategic success of any country. What really matters is which technology such a country is developing (imitating) and implementing.

\section{METHODOLOGICAL APPROACH TO ASSESSING TECHNOLOGY GAPS IN INDUSTRY 4.0}

The proposed methodological approach to the assessment of technology gaps is based on several assumptions. 
Firstly, this refers to turbulent, disruptive rather than laminar (gradual) technological development. In general, both approaches have the right to a scientific life, and it all depends on the circumstances, place, and time. Now, we deal with the fourth industrial revolution, and it is time to analyze the realities of disruptive development usually described by the concept of technology life cycle and leap transitions between technology curves.

Secondly, since we analyze comparisons of countries as a whole, i.e. deal with macro- rather than micro-economic indicators, this refers to groups of dominant technologies in a particular country, which define the overall technical and technological level of national economies, rather than individual technological solutions that can be relevant to different technological structures.

Thirdly, it takes into account what are the main features of the new dominant technologies, since it is of fundamental importance for identifying the factors that influence their development and for parameterizing the S-curves.

The currently emerging Industry 4.0 is the product of new, fourth industrial revolution. This industry, firstly, is based on digital revolution and, secondly, is characterized by fusion of innovative technologies that blur the lines between the physical, digital, and biological spheres [35, 11-12].

The core of this industry is the "smart" cyberphysical systems that are creating a new society that can no longer be called either industrial (production of goods) or post-industrial (provision of services). In general, they are qualitatively different. They are cybernetic and physical at the same time, with its hybrid products being neither goods nor services exclusively [4, 20]. Cyberphysical technologies and artificial intelligence make it "smart" and build on this basis a new smart society that the Japanese have already called society 5.0 [36].

In this context, the famous industrial-postindustrial dichotomy loses its meaning. In the smart

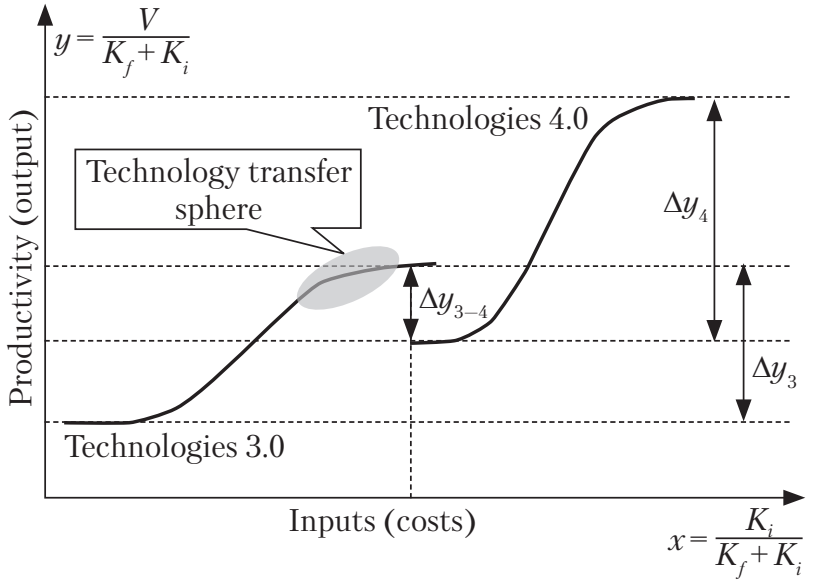

Fig. 2. Description: $K_{i}$ is digital capital; $K_{f}$ is physical capital; $V$ is value added; $\Delta y_{3}$ is capacity of technology 3.0 in terms of productivity; $\Delta y_{4}$ is capacity of technology 4.0 in terms of productivity; $\Delta y_{3-4}$ is temporary loss of productivity while transiting from technology 3.0 to technology 4.0

society with new smart production, hardware and software organically complement each other and co-evolve. However, the limits of the possibilities of this co-evolution are still determined by the development of hardware rather than software. To clarify this view, let us return to the concept of the technology life cycle, in which the relationship between the costs of creating and promoting new production technologies and the results obtained are described by (logistic) technology curves (Fig. 2).

As mentioned above, the economic meaning of these curves is that, at first, when a new technology starts its life, efforts to develop it tend to yield modest results, because creating new settings and manufacturing processes, methods and tools requires time and money. However, later, as a result of these efforts, the new technology unleashes its potential $\left(\Delta y_{4}>\Delta y_{3}\right)$ (provided the ideas embodied in it are correct and true) and brings growing returns, including by means of information and communication technologies. Finally, at the stage of maturity, further investment in the improvement of technology results in a small increase in its physical performance.

This means that the capacity of such engineering solution is largely exhausted, and it can no 
longer be enhanced by any kind of digital tricks. In other words, if you use old hardware, even the best "software" and management methods based on it cannot raise the overall performance of the system above a certain level. Therefore, it is necessary to find new engineering solutions and to leap to new technology curves, even if this process is accompanied with temporary economic losses $\Delta y_{3-4}$ in Fig. 2).

Inasmuch as in Industry 4.0, the development of production technologies is most closely linked to the development of digital technologies, the conceptual approach illustrated in Fig. 2 is distinguished by the fact that the cost is described by change in the capital structure (the share of digital capital $K_{i}$ in its total value, i.e. the sum of the digital and the physical capitals), so that a greater share of $K_{i}$ corresponds to more efficient production technology.

This is generally in line with current practice. For example, in Germany as one of the leaders in Industry 4.0, the growth in industrial output and labor productivity is mainly driven by the software component [36, 28-32]. In many advanced economies, the digital (rather than the physical) capital, especially, its intangible part, has been showing a leading growth pace. On average, globally, investments in digital intangible assets account for about $50 \%$ of investments in digital tangible assets. However, in Israel, Japan, Sweden, the United Kingdom, and the United States this ratio makes up about 70\% [38].

As already noted, maximum proceeds are reached at the stage of physical maturity, when the technology is well-developed. Therefore, such "mature" technologies are worth to export (the sphere of technology transfer in Fig. 2). Those countries that buy, adapt, and implement them in order to enhance their economies always lag behind the technological leaders who are able to invest the proceeds from use and sale of mature technologies in new generations of engineering and design solutions that are potentially more profitable, as compared with the previous generations of technology. In terms of Fig. 2, the initial losses from transition to technology 4.0 can be greatly offset by an increase in their physical productivity and financial gains. Moreover, as shown in Fig. 2, the slope angle of the middle part of the S-curve of technology 3.0 is less than that of technology 4.0 .

It is possible and appropriate to extend this concept to the field of technological development of national economies that use dominant technologies ${ }^{6}$ of different levels and degrees of development. That is, for a particular national economy, shift to the right between the points of the same S-curve can be interpreted as the development of dominant technologies of a given level. This statement is the key hypothesis and starting point for the further calculations based on historical economic data.

Let us consider the three countries: Ukraine, and the two EU members, the Czech Republic and Germany. As you know, Ukraine today is characterized by a relatively low technological development. The industries that underlie its industrial potential (basically, fuel, power engineering, and metallurgy) represent the technology 3.0 or lower ${ }^{7}$. The situation in Germany as the EU leader is completely opposite, as by many attributes its industry can be referred to Industry 4.0. The Czech Republic that traditionally belongs to the industrialized economies occupies an intermediate position, so that its industry can be described as Industry $3+$.

According to the concept proposed above, we assume that in each national economy, productivity (output) is a function of costs (investments in physical and digital capital; so that physical capital cannot grow without investment in digital capital) and level of R\&D development. In this case, we consider labor productivity (GDP per capita) as outcome and capital-labor ratio (re-

${ }^{6}$ This means exactly dominant (widely used) technologies, not single cases of technologies that do not have any material effect on the situation in economy.

${ }^{7}$ Both extraction industry and metallurgy can be upgraded based on "smart" principles, however, this is not the case for Ukraine, at the moment [39]. 

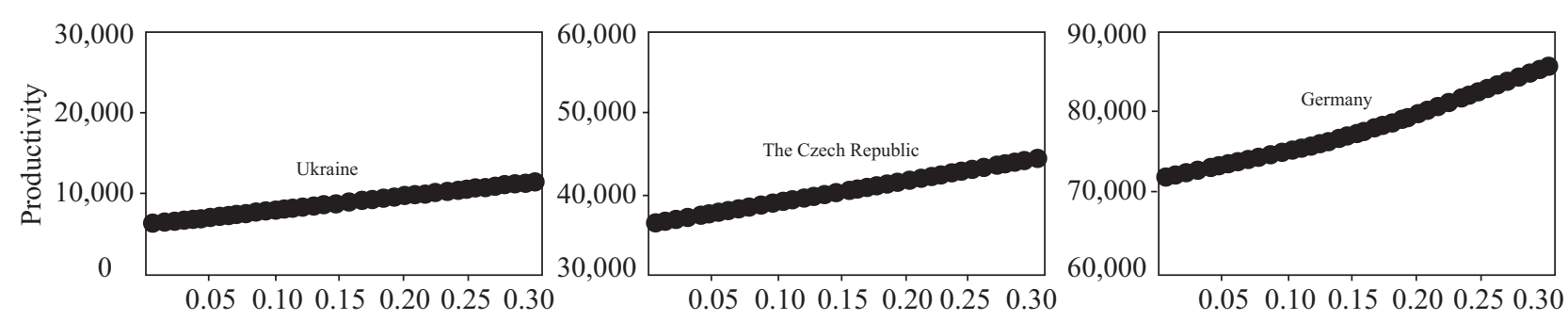

Capital-labor ratio (USD million per capita)

Fig. 3. Dependence of productivity on capital-labor ratio in Ukraine, the Czech Republic, and Germany. Capital-labor ratio in Ukraine: USD $0.007-0.010$ million per capita, in the Czech Republic: USD $0.12-0.17$ per capita, in Germany: USD $0.23-0.30$ million per capita

sidual value of fixed assets per capita) as inputs. In fact, this is a classic dependence of labor productivity on its capital-labor ratio.

Each country develops its dominant technologies so that higher investments $(x)$ correspond to higher output $(y)$. However, this dependence is $\mathrm{S}$-shaped, not linear, which is described by the following formula of the logistic curve:

$$
y=\frac{A}{1+10^{a-(1+\mu) x}}+C,
$$

where $A$ is parameter that defines the lower limit of the logistic curve; $C$ is parameter that defines the difference between the upper and the lower limits of the logistic curve; $a$ is parameter that defines the effect of scientific and technical progress (labor productivity dependence on R\&D expenditure); $\mu$ is parameter that describes physicalto-digital capital ratio.

Function (3) is parametrized using MS Excel tools and statistical data for several years ${ }^{8}$. The results are shown in Fig. 3.

Apparently, even if Ukraine reaches the capital-labor ratio of the Czech Republic and Germa-

\footnotetext{
${ }^{8}$ The model parameterization is based on the statistics of the analyzed countries for 2005-2018 (except 20082009 , when there was a global financial crisis, which caused sharp changes in economic indicators). In this case, the parameter $a$ that defines the impact of scientific and technological progress is defined based on the results of correlation-regression analysis of variables describing $R \& D$ expenditure [46] and world labor productivity, and parameter $\mu$ characterizing the physical-to-digital capital ratio is found based on McKinsey \& Co. data [38]. Other model parameters are calculated using the MS Excel add-in Solution Search.
}

ny, it is not able to catch up with them in terms of productivity unless the country changes the development trends of the last decade. That is, since technologies 3.0 are dominant, even the mass introduction of innovations, including those based on purchased technologies (sphere of technology transfer in Fig. 2) does not enable addressing the problems of competitiveness of the national economy and moving up from "raw material colony" for advanced economies to the "new industrial tiger" with dominant technologies 3.0+ and 4.0. At the same capital-labor ratio (USD 0.1 million per capita, if Ukraine manages to have reached it), the technology gap as measured in productivity lag, is: Ukraine's productivity is 5 times lower than in the Czech Republic (i.e., about USD 30,000 per capita) and 10 times lower than in Germany (about USD 65,000 per capita).

Naturally, the trends based on historical data do not say anything about how the situation changes if the country makes a breakthrough accompanied with a transition to a new technology curve. This is quite likely. However, it is important to understand that such a transition is an extremely complex process rather than a mere engineering task or a financial problem (since the technology gap cannot be closed by "pouring" it with money). Technologies are developed not in a vacuum, they need a favorable cultural and institutional environment. Recent developments in the institutional and evolutionary theories in economics have testified to this, saying that, for success, we need mainly inclusive rather than extractive institutions [40], developed cultural capital [41], 


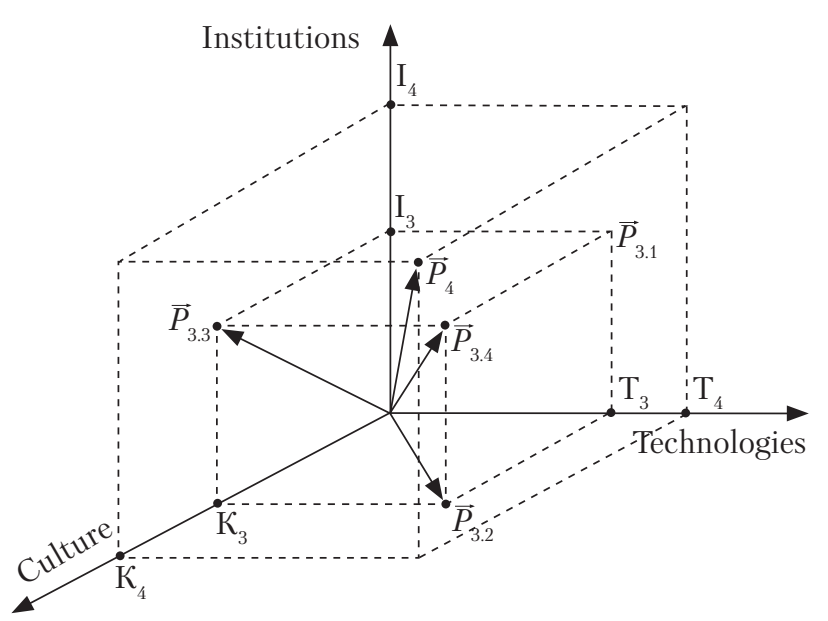

Fig. 4. Alternative ways of business ecosystem development in Ukraine

and organizational routines that meet the hi-tech demands [42], i.e. all that in the complex can be called an appropriate, innovation-oriented business ecosystem (Fig. 4).

In biology, ecosystems are commonly understood as collection of living organisms in combination with non-living environment components that interact as a single system. In economics, ecosystems are dynamic stable networks of diverse interconnected enterprises and institutions (including cultural ones) operating within a limited geographical area $[43,1]$. From our point of view, the basic idea of the ecosystem (the theory of which is rapidly evolving in the economy) is the concept of gene-cultural-technological coevolution. This means, in addition to innovation, the desired transition to Industry 4.0 (vector $P_{4}^{1}$ ) requires simultaneous transformations in institutions and culture, which cannot be achieved quickly, since it takes a long time for gradual and consistent progress. As J. Diamond puts it, one cannot simply share the experience of effective institutions with poor countries like Paraguay and Mali and expect that they use the knowledge they have gained and catch up with the United States and Switzerland on GDP per capita. Effective institutions are not a random parameter that could appear with equal probability in any society on the planet, be it Denmark or Somalia. From his point of view, effective institutions have always arisen as a result of a long chain of historical accomplishments - the ascent from the original geographical factors to those derived from them, including institutional ones [44, 561].

As of today, the more realistic vectors of development for Ukraine are vectors of technological development of Industry $3.0\left(\vec{P}_{3.1}, \vec{P}_{3.2}, \vec{P}_{3.3}, \vec{P}_{3.4}\right)$, although, it is clear that in this case, Ukraine remains within the category of technoloogy gap rather than the more desirable technology lag.

However, there is much to be done for it. First of all, as it is emphasized in [45], there is an urgent need for accelerated development of the R\&D sphere, which relevant institutions (including organizational routines) and culture are linked to. Following the example of the EU, the creation of high-level groups on key technologies in Ukraine, the definition and periodic update of the national list of these technologies, the increase in $\mathrm{R} \& \mathrm{D}$ funding to, at least, $2 \%$ of GDP ${ }^{9}$, the encouragement of private $R \& D$ funding and the increase of its share in the total financing up to $50 \%$ [47, 121], as well as many other measures can be the first steps on the path towards the aforementioned goals.

\section{CONCLUSIONS}

The pace of technology transformations in the world is accelerating as the fourth industrial revolution unfolds. A new geo-economic and geopolitical reality is emerging, with leaders in the development and application of Industry 4.0 technology playing a key role in this process. In this regard, the concept of technology gap is very important. It is vital for Ukraine to define its place

${ }^{9}$ According to the World Bank, in 2005-2017, the share of R\&D in Ukraine's GDP accounted for $0.45 \%$ versus $1.11 \%$, in Russian Federation; 2.13, in China; 2.80, in the United States; and 3,04, in Germany, given the fact that Ukraine's GDP per capita was a small fraction of that in the mentioned countries. Unlike in the advanced economies, in Ukraine, $\mathrm{R} \& \mathrm{D}$ sector is funded mainly at the expense of government, not the private sector, that means the national economy has such an institutional structure that does not encourage innovations. 
in the global transformations and to understand how far it is lagging behind the industrial leaders and what it needs to do for, at least, reducing instead of increasing the gap. After all, if the technology gap is growing, all European integration intentions are worthless. Otherwise, this integration may make Ukraine a raw material colony for the industrialized European economies and a place of concentration of dirty technologies.

There are different approaches to identifying gaps based on theories of international trade, innovation, technology life cycle, evolutionary economy, micro- and macro-levels developed by various organizations, etc. Their critical review has led to the emergence of a new vision based on the technology life cycle theory. It has been proposed to distinguish between technology lag and technology gap.

Technology lag is a small difference in technological development, mainly, between countries with similar income, which are developing within similar technological paradigm. Technology gap is a significant distance between countries in terms of technological development, the emergence of which is possible in the two ways:

1) between countries with similar income and the same technological structure in the case of a large-scale disruptive innovation belonging to a higher technological structure, in one of them, or in the case of massive evolutionary innovations;
2) between economies with different technological structure.

Using the developed approach, the technology gap between Ukraine and industrialized European economies has been empirically estimated based on the concept of S-curves. For this purpose, there has been built a logistic function that describes the relationship between labor productivity and capital-labor ratio, with the interdependence of physical and digital capital taken into account. It has been found that at the same capital-labor ratio of USD 0.1 million per capita, productivity of Ukraine is 5 times lower than in the Czech Republic (i.e., by about USD 30,000 per capita) and 10 times lower than in Germany (by about USD 65,000 per capita).

Closing this gap is an extremely complex process rather than a mere engineering task or a financial problem (so, the problem cannot be solved by means of money only). The first step on this path shall be a set of measures to accelerate the development of R\&D sector and related culture and institutions.

The research has been carried out within Technology Gaps and Ways of Closing Them in the Conditions of Global Instability project under Reconstruction of the Ukrainian Economy: Historical Challenges and Modern Projects target scholarly research program of the NAS of Ukraine.

\section{REFERENCES}

1. World Economic Forum. (2015). Industrial Internet of Things: Unleashing the Potential of Connected Products and Services. Cologny/Geneva, Switzerland: World Economic Forum.

2. Miebach Consulting. (2017). Miebach's nearshoring study shows: the production is being relocated closer to the industrialized countries. Miebach Consulting. URL: https://www.miebach.com/en/publications/?publication=203 (Last accessed: 07.08.2019).

3. European Commission, Directorate-General for Research and Innovation. (2018). Re-finding Industry - Defining Innovation. Report of the independent High Level Group on industrial technologies. Brussels: European Commission.

4. Smit, J., Kreutzer, S., Moeller, C., Carlberg, M. (2016). Industry 4.0: Study. Brussels: European Union.

5. Vishnevsky, V. P., Kniaziev, S. I. (2017). Smart-industry: prospects and problems. Economy of Ukraine, 7(660), 22-35 [in Russian].

6. European Commission. (2016). Key Enabling Technologies - Internal Market, Industry, Entrepreneurship and SMEs. European Commission. URL: https://ec.europa.eu/growth/industry/policy/key-enabling-technologies_en (Last accessed: 09.11.2019).

7. McKinsey \& Company. (2013). Disruptive technologies: Advances that will transform life, business, and the global economy. New-York, USA: The McKinsey Global Institute. 
8. McKinsey Global Institute. (2017). A future that works: automation, employment, and productivity. New-York, USA: McKinsey \& Company.

9. Lawrence, M., Roberts, C., King, L. (2017). Managing Automation. Employment, inequality and ethics in the digital age. IPPR Commission on Economic Justice. Discussion Paper. IPPR 2017.

10. Global Innovation Index. (2019). Global Innovation Index (GII) 2019: Creating Healthy Lives - The Future of Medical Innovation. Global Innovation Index. URL: https://www.globalinnovationindex.org/Home (Last accessed: 09.11. 2019).

11. Harvard's Growth Lab. (2019). The Atlas of Economic Complexity. Harvard's Growth Lab. URL: http://atlas.cid. harvard.edu/rankings/ (Last accessed: 09.11.2019).

12. IMD business school. (2019). IMD World Digital Competitiveness Ranking 2019. IMD business school. URL: https:// www.imd.org/wcc/world-competitiveness-center-rankings/world-digital-competitiveness-rankings-2019/ (Last accessed: 09.11.2019).

13. Godin, B. (2010). Conceptual foundations of scientific, technological and innovation policy. Foresight and STI Governance, 2(2), 34-43 [in Russian].

14. Heckscher, E. F. (2006). The impact of foreign trade on income distribution. Milestones in Economic Thought. P. 154173. In International Economy (Ed. A .P. Kireev). V. 6. Moscow: TEIS [in Russian].

15. Posner, M. V. (1961). International trade and technical change. Oxford Economic Papers,13(3), 323-341. doi: 10.1093/ oxfordjournals.oep.a040877

16. Jones, R. (1970). The Role of Technology in the Theory of International Trade. In The Technology Factor in International Trade (Ed. R. Vernon). Cambridge, MA: NBER. P. 73-94.

17. Foster, R. (1986). Innovation: The Attacker's Advantage. New York: Summit Books.

18. Foster, R. (1987). Innovation: The Attacker's Advantage. Moscow: Progress [in Russian].

19. Fagerberg, J. (1988). International competitiveness. Economic Joumal, 98(391), 355-374.

20. Nelson, R. R., Winter, S. G. (2002). An Evolutionary Theory of Economic change. Moscow: Delo [in Russian].

21. Fagerberg, J., Verspagen, B. (2002). Technology-gaps, innovation-diffusion and transformation: an evolutionary interpretation. Research policy, 31(8-9), 1291-1304.

22. Peres, C. (2002). Technological revolutions and Financial capital. The dynamics of bubbles and Golden ages. Cheltenham, UK: Edward Elgar.

23. Peres, C. (2011). Technological revolutions and Financial capital. The dynamics of bubbles and Golden ages. Moscow: Delo Publishing House, ANE [in Russian].

24. Kondratieff, N. D. (2002). Big business cycles and foresight theory. Moscow: Economy [in Russian].

25. Schumpeter, J. A. (1982). History of Economic Analysis. Moscow: Progress [in Russian].

26. Lennerfors, T. T., Fors, P., van Rooijen, J. (2015). ICT and environmental sustainability in a changing society. Information Technology \& People, 28(4), 758-774. doi: 10.1108/ITP-09-2014-0219

27. Hirooka, M. (2006). Innovation Dynamism and Economic Growth. A Nonlinear Perspective. Cheltenham; Northampton (MA): Edward Elgar.

28. Akayev, A. (2011). The mathematical foundations of the Kondratieff-Schumpeter innovation-cyclic theory of economic development. Bulletin of the Institute of Economics RAS, 2, 39-60 [in Russian].

29. Dementiev, V. Ye. (2016). Long waves in the economy: institutional aspect. In Crises and forecasts in the light of the theory of long waves (Eds. L.Ye. Grinin, A.V. Korotayev, R. S. Grinberg). Moscow: Moscow editors' office of Publishing house Uchitel. P. 124-139. [in Russian].

30. The World Bank. (2008). Technology E Development. Findings from a World Bank Report Global Economic Prospects 2008: Technology Diffusion in the Developing World. Washington, DC: The International Bank for Reconstruction and Development / The World Bank.

31. Mühleisen, M. (2018). The Long and Short of the Digital Revolution. Finance E⿱ Development, 55(2), $1-2$.

32. Vesperoni, E., Bluedorn, J., MacDonald, M. (2018). Future of work: measurement and policy challenges. Washington, DC: International Monetary Fund.

33. Deloitte (2019, 22 January.). Closing technology, Talent Gaps for Industry 4.0. The Wall Street Journal. URL: https:// deloitte.wsj.com/cio/2019/01/22/closing-tech-and-talent-gaps-for-industry-4-0/ (Last accessed: 09.11.2019).

34. Caldwell, L. (2019, 11 January). Industry 4.0 Holds the Key to Closing the Manufacturing Industry's Skills Gap. Forbes. URL: https://www.forbes.com/sites/lisacaldwell/2019/01/11/industry-4-0-holds-the-key-to-closing-the-manufacturingindustrys-skills-gap/\#175b24f44ae2 (Last accessed: 09.11.2019).

35. Schwab, K. (2016). The Fourth Industrial Revolution. Moscow: Eksmo. [in Russian]

36. Government of Japan (2015, December 18). Report on the 5th Science and Technology Basic Plan. Tokyo: Council for Science, Technology and Innovation Cabinet Office.

37. Madykh, A. A., Okhten, O. O.(2018). Modeling the transformation of the impact of production factors on the economy in the process of smart industry formation. Econ. promisl., 4 (84), 26-41 [in Russian]. doi: 10.15407/econindustry2018.04.026 
38. Bughin, J., Manyika, J. (2013, July). Measuring the full impact of digital capital. McKinsey Quarterly.

39. Amosha, O. I., Nikiforova, V. A. (2019). Metallurgical Smart Industry Development: Global Experience and Lessons for Ukraine. Economy of Ukraine, 9-10, 3-23 [in Ukrainian].

40. Acemoglu, D., Robinson, J. (2016). Why Nations Fail: The Origins of Power, Prosperity, and Poverty. Moscow: AST [in Russian]. 41. Harrison, L. (2014). Jeres, Confucians, and Protestants: Cultural Capital and the End of Multiculturalism. Moscow: Misl' [in Russian].

42. Hodgson, G. M. (2003). The Mystery of the Routine. The Darwinian Destiny of an Evolutionary Theory of Economic Change. Revue économique, 54 (2), 355-384.

43. Auerswald, P., Dani,L.(2018). Economic Ecosystems. In The New Oxford Handbookof Economic Geography (Eds. G. L. Clark, M. P. Feldman, M. S. Gertler, D. Wójcik). Oxford University Press. doi: 10.1093/oxfordhb/9780198755609.013.47

44. Diamond, J. (2010). Guns, Germs, and Steel: The Fates of Human Societies. Moscow: AST [in Russian].

45. Vishnevsky, V. P., Kniaziev, S. I. (2018). How to increase the readiness of Ukraine's industry to smart transformations. Nauka innov., 14 (4), 55-69 [in Ukrainian]. doi: 10.15407/scin14.04.055.

46. The World Bank. (2019). World Development Indicators: Science and technology. The World Bank. URL: http://wdi. worldbank.org/table/5.13\# (Last accessed: 14.11.2019).

47. Vishnevsky, V. P., Harkushenko, O. M., Kniaziev, S.I., Chekina, V. D., Hrechyshkin, O. V. (2018). The Transformational Potential of Digitizing the Ukrainian Economy: The R\&D Report (Final). NDR 0118U002109. Kyiv: The Institute of Industrial Economics, NAS of Ukraine [in Ukrainian].

Received 14.11.19

Revised 22.11.19

Accepted 25.11.19

В.П. Вишневський ${ }^{1}$, О.М. Гаркушенко ${ }^{1}$, С.І. Князєв²

${ }^{1}$ Інститут економіки промисловості НАН України,

вул. Марії Капніст, 2, Київ, 03057, Україна,

+380 44200 5571, vishnevsky@nas.gov.ua

${ }^{2}$ Відділення економіки НАН України,

вул. Володимирська, 54, Київ, 01030, Україна,

+380 44239 6646, ksi@nas.gov.ua

\section{ТЕХНОЛОГІЧНІ РОЗРИВИ: КОНЦЕПЦІЯ, МОДЕЛІ, ШЛЯХИ ПОДОЛАННЯ}

Вступ. Розгортання четвертої промислової революції та прискорений розвиток проривних технологій Індустрії 4.0 супроводжуються формуванням у світі нових мереж створення вартості й перерозподілом виробничих потужностей, що частково повертаються до розвинених країн.

Проблематика. Процес технологічного розвитку й формування нових мереж створення вартості є турбулентним, так що одні країни стають новими технологічним лідерами, а інші - аутсайдерами. Між ними виникають нові або змінюються уже наявні технологічні розриви, а це, у свою чергу, критично позначається на розвитку національних економік: продуктивності праці, створенні нових робочих місць, прибутковості бізнесу, зайнятості та доходах населення.

Мета. Розробити концептуальний підхід до визначення поняття і оцінювання розмірів технологічних розривів між країнами з різним рівнем розвитку промисловості в умовах четвертої промислової революції.

Матеріали й методи. Історичний аналіз економічних концепцій технологічних розривів, статистичний аналіз показників економічного й науково-технічного розвитку країн світу, економіко-математичне моделювання життєвого циклу кіберфізичних технологій.

Результати. У рамках економічної теорії життєвого циклу технологій запропоновано уточнене поняття технологічного розриву як такого, що пов'язаний переважно з стрибкоподібним переходом з однієї технологічної кривої до іншої. Для оцінки величини технологічних розривів запропоновано логістичну функцію, яка визначає залежність між продуктивністю праці та їі фондоозброєністю з урахуванням взаємозалежності фізичного й цифрового капіталу. 3 iї використанням визначено технологічні розриви між Україною та індустріально розвиненими європейськими країнами, що вимірюються кількаразовим відставанням у продуктивності праці.

Висновки. Для зменшення технологічних розривів між Україною та європейськими країнами необхідним є створення нової, орієнтованої на інновації бізнесової екосистеми, яка формується у процесі генно-культурно-технологічної коеволюції та потребує, насамперед, комплексу заходів щодо прискорення розвитку науково-технічної сфери України та пов'язаних з нею культури та інститутів.

Ключові слова: промислова революція, технологічний розрив, кіберфізична технологія, технологічна крива, бізнесова екосистема. 